\title{
Rural Youth, Agriculture, and Entrepreneurship: A Case-Study of Hungarian and Romanian Young Villagers
}

\author{
Şerban OLAH \\ Department of Sociology and Social Work \\ University of Oradea, Romania \\ e-mail address: serbanolah2002@yahoo.com \\ Gavril FLORA \\ Department of Social Sciences \\ Partium Christian University of Oradea, Romania \\ e-mail address: gavrilflora@yahoo.com
}

\begin{abstract}
This paper analyses the involvement of Romanian and Hungarian young villagers in the local agriculture and entrepreneurial activities. The first part provides an outlook on the historical evolution and the current situation of agriculture and rural development in Romania and Hungary from the perspective of theoretical positions formulated within economics and the sociology of entrepreneurship as well as rural sociology. The second part discusses the results of a cross-border research and social intervention project conducted in the period of 2012-2013 in ten rural localities from the shared Hungarian-Romanian border region. The questionnaire included questions regarding rural youth integration in the labour market, agriculture, and involvement in entrepreneurial activities as well as social and religious participation. The research has found significant differences between Romanian and Hungarian young villagers with respect to the examined questions.
\end{abstract}

Keywords: rural youth, agriculture, entrepreneurship, border region, Romania, Hungary

JEL codes: Q1-Agriculture, R1-General Regional Economics, Y8-Related Disciplines

\section{Introduction}

Literature characterizes rural areas as areas with small density of population, high level of unemployment, low productivity, low income of the population, and the very important role of agricultural activity. In the general process of population aging, the topics regarding youth and the role of the young generation 
in economic activity become very important. These considerations have led us in choosing the topic of the present paper.

The idea of this comparative research emerged from the need to integrate the euroregional outlook and the cross-border approach into the research and development activities within the shared border region of Romania and Hungary. Based on the comparative research data collected during the cross-border project, our paper focuses on the rural youth as a vulnerable group with difficulties of integration in the labour market. The main aspect that interests us, however, is the involvement of the young villagers in entrepreneurial activities and local agriculture, viewed as potential solutions both for rural development and for attenuating the rural unemployment of the young population segments by providing them important means of integration into the local and regional economy.

The focus of the paper is the rural youth and its involvement in agriculture and entrepreneurship.

One of the concrete practical reasons for initiating this social intervention project and the comparative research which was part of it derives from the fact that both in Romania and Hungary youth is the most affected group by unemployment. In 2014, the specific unemployment rate for the group of young people under the age of 25 was $15.7 \%$ in OECD countries, while in the EU member's states it was $23.4 \%$. In Romania, it reached $25.7 \%{ }^{1}$ and in Hungary was as high as $27.2 \% .^{2} \mathrm{~A}$ similar situation also characterizes the shared border region of the two states. In 2011 in Bihor County (Romania), the young people who were at the beginning of their professional careers made up $21.38 \%$ of the registered unemployed, ${ }^{3}$ while in Hajdú-Bihar their proportion was approximately $11 \%$ in $2010 .{ }^{4}$

Being aware of the strong social need to improve our understanding of villages and villagers, in the period of 2012-2013, two partner universities, the University of Oradea in Romania and the University of Debrecen in Hungary, implemented a cross-border project with the aim to promote their integration on the euro-regional labour market (Bihor - Hajdú-Bihar Euro-region). By means of analysing socio-economic data and formulating recommendations for public policy decision-makers, the project aimed at contributing to the enhancement of economic competitiveness and the improvement of human resources within the Hungarian-Romanian cross-border area. Its specific objectives were to offer information, counselling, and orientation and to provide institutionalized training services for the rural youth. The direct target group of the project consisted of 300

1 http://www.capital.ro/somajul-in-randul-tinerilor-a-ajuns-la-257-in-romania.html (accessed on: 3.11.2014).

2 http://index.hu/chart/2014/09/24/oecd/ (accessed on: 12.10.2014)

3 http://adlearning.creathink.ro/uploads/publicari/12918_researchstudy\%20hu\%20jo.pdf (accessed on: 15.09.2014)

4 http://www.dehir.hu/hajdu-bihar/nott-a-munkanelkuliseg-a-megyeben/2011/01/17/ (accessed on 16.09.2014) 
youngsters, 150 from each country, and 30 of each of the 10 rural localities. In the first phase of the project, a comparative cross-border research was implemented, inquiring into the factors influencing the integration process. ${ }^{5}$

In light of the research data, rural youth can rightly be considered as a vulnerable group, with the meaning of a marginalized group, excluded group, or risk group. All these concepts are in relation with the phenomenon of poverty and social exclusion. The most frequent meaning of vulnerability is that of weakness, lack of defence, or lack of means. The vulnerable groups are those groups where the support lacks and which are often in poverty and cannot use the opportunities or defend themselves in front of the problems they face. Another meaning of vulnerability is the risk that can lead a person to a poverty level which is under a limit that is acceptable by the society. In this larger meaning could be found the young graduates on the labour market, the rural youth on labour market, and the people who migrate for work (Popescu, 2011).

To understand why the rural youth of Romania and Hungary has become a vulnerable group, we will first need to discuss, from the perspective of theoretical positions formulated within economics and the sociology of entrepreneurship, how the rural world developed in Romania and Hungary and what have been the main social and economic transformations of the rural society in both countries during socialism and post-socialism. Building upon this diagnosis, we will then proceed to the analysis of our research data.

The first part of the paper presents the reasons for studying this topic and discusses some theoretical aspects such as entrepreneurs and entrepreneurship (Section 2), the Romanian and the Hungarian rural society (sections 3, 4), and the entrepreneurial environment in Romania and Hungary (Section 5). The second part of the paper presents the research methodology and the results (sections 7 to 11). The last section presents some conclusions.

\section{Entrepreneurs and Entrepreneurship}

\subsection{Economy and Sociology of Entrepreneurship}

The attitude towards risk is a specific feature of people. Few people assume risks when others do not prefer to risk. Between these two types of people, there is, however, a strong similarity, as rightly pointed out by Peter Drucker, one of the main leaders of management science. Those who assume the risk and those who do not assume the risk make two main mistakes throughout a year (Doltu, 2011). The focus of this part of the paper is an analytical debate concerning those people who decide to assume risks, and therefore we use to call them entrepreneurs.

5 http://www.territorialcooperation.eu/frontpage/show/23625 (accessed on: 25.11.2014) 
It is very curious that the word "entrepreneurship" is rarely mentioned in the manuals of economics. The word "entrepreneur" is absent from the writings of Adam Smith or David Ricardo. Marx is not focusing on "entrepreneur" either but rather on the process of work, the control and the leadership of workforce. The first great economist who uses the word "entrepreneur" is the French Richard Cantillon. In his view, the entrepreneur is a speculator.

In the economic thinking of Walras, the employer is the entrepreneur; however, entrepreneurship is not a production factor but rather a function of an agent, for instance the capitalist or the manager. As "marginalism" became the basic paradigm of economics, it is not curious that all the current economics manuals are rich in information with regard to the consumer's behaviour, profit maximization, the wage theory, or the theory of international trade, but are very poor in approaching topics such as technical change, the development of big businesses, the causes of welfare and poverty of nations, and the theory of entrepreneurship (Swedberg, 2000).

The great Austrian economist, Joseph Schumpeter, provides an analysis of entrepreneurial behaviour in his book "The Theory of Economic Development" published in 1911. In this work, the entrepreneurship and its connection with the dynamic incertitude is at the centre of his economic analysis. Schumpeter considers that only technical innovations and dynamic change can produce a positive rate of the profit. He distinguishes between invention and innovation. The main actors of economic life are in the view of Schumpeter: the entrepreneur, the banker, and the owner of production means. The enterprise is the result of a new combination of means of production, when the entrepreneur's function is the realization of this combination. The entrepreneurial success depends on intuition. The entrepreneur is, as Schumpeter very well put it, "a swimmer who swims against the stream" (Swedberg, 2000).

We have to add that, according to American economist Peter Drucker, "Joseph Schumpeter was the only modern important economist who focused on the entrepreneur and his impact on economy. Every economist knows that the entrepreneur is important and has an influence on economy. But for economists the entrepreneurial system is a meta-economic event, something that deeply influences and models economy without being part of it. Economists do not have an explanation of the entrepreneurial phenomenon: why has it risen at the end of $19^{\text {th }}$ century as it is now and it is limited in a country and in a culture. The events which explain why entrepreneurial system becomes efficient are not economic events themselves" (Drucker, 1993).

In an article dedicated to the comparative analysis of the Austrian school and Schumpeter's position with regard to the entrepreneur and entrepreneurship, Alin Croitoru considers that one of the main distinctions between these two 
positions is related to the way they analyse the economic environment where entrepreneurial activity takes place (Croitoru, 2013).

One of the main current contributions to the topic of entrepreneurship is the one by Baumol (2009). He considers that the economic advancement of societies such as the United States of America, Ireland, or Israel in comparison with Continental Europe could be explained through the inclination of the mentioned economies towards innovation and entrepreneurship. If the political leaders of a country were to seek the long-term economic growth, they should create the conditions for the entrepreneurial capitalism of big companies.

Which are these conditions? The first condition is connected with the easiness of initiating and developing a business. The second one is the protection against bankruptcy, which is vital for the promotion of entrepreneurship because in its absence many potential entrepreneurs would not assume any risk of initiating a business. The third condition is the access to credit. Baumol quoted two main economists, Amarante and Phelps, who considered that bankers were the channel through which innovations could be transformed from simple ideas into sources of economic growth. Other conditions for stimulating entrepreneurship are the governmental support for research and development, the anti-trust laws, the trading and investment promotion, and rewarding of new ideas (Olah, 2013).

We mentioned earlier that economic sociology has many contributions on the topic of entrepreneurs and entrepreneurship. If the economists are focused on economic factors which favour or inhibit the entrepreneurial activity, then the sociologists are focused on factors such as religion, kinship, ethnicity, social capital, or cultural capital. Maybe the first major contribution that can be regarded is that of Max Weber, who suggested that industrialization and capitalism rose in the West because the values derive from the Protestant Ethic. While in other ages the social and religious ethos inhibited the rational and systematic development, the values derived from the Protestant Ethic encouraged the capitalist behaviour (Olah, 2013).

Mark Granovetter analysed in a book published in 2000 "how is it possible for entrepreneurs to assemble capital and labor required to sustain the cooperative venture we call a firm" (Swedberg, 2000, p. 244). His analysis is focused on the roles played by trust, ethnicity, and kinship, offering a special attention to rotating credit associations from Japan, China, and Southeast Asia. He concludes that discussions on rotating credit associations show that "solidarity required for assembling coherent combinations of economic activity depends on a well-defined collection of people who identify each other as belonging to the same collectivity by ethnicity or even more markers such as place of origin" (Swedberg, 2000, p. 255). 


\subsection{Rural Entrepreneurship}

What represents the rural world?, was asking himself Bogdan Voicu, one of the most gifted Romanian sociologists from the young generation, in a book published in 2006. His answer is pointing to "a fascinating world, where eternity has been born for most of us. A world with unwritten stories, with oral traditions, with hens and sheep... a world of difference for most Western Europeans... a poor world by current standards, but with very rich in understandings and meanings" (Voicu \& Voicu 2006, translation by authors).

A somewhat different opinion attempting to take into account the effects of modernization as well is expressed by Eugen Crihan in a recent book. He believes that "the rural is often perceived as the sheer opposite of the urban. There are two major prejudices. The first one is to consider the rural space as a place of historical backwardness (and of course that of conservative-traditionalist mentalities) [...] The second one is the identification of the rural with the peasantry..." (Crihan, 2011, p. 15, translation by authors). These two prejudices are hidden under the neutral formula of the urbanization level considered as a synthetic indicator of the development level of every social space. Under this formula, rural is considered a socio-economic situation defined by the existence of many peasants. However, this perception is "without object because the backward and conservative peasant is in a process of extinction following the general trend of modernity" (Crihan, 2011, translation by authors). What definition can we give to rural entrepreneurship? An answer to this question could be: "a force which mobilizes other resources for covering an unsatisfied demand of the market" (Doltu, 2011). There are many cases of successful rural entrepreneurship in countries such as the United States of America, Colombia, Paraguay, or Bulgaria. The diversification of using nonagricultural available resources through the entrepreneurial combinations created diverse forms such as tourism, offering conditions for sport and entertainment or training, small trading, industrial activities, and consultancy or productive activities such as meat, wood, or milk producing (Doltu, 2011).

Why is rural entrepreneurship important for rural development? First of all, it can increase the number of jobs within the agriculture. This increase has several effects: decrease in poverty, increase of income per capita, and higher chances for discouraged workers to come back to the labour market. Rural entrepreneurship has, however, also some potential barriers: the market potential, the low density of population, the small income of the population, the consumption habits, the precarious infrastructure, the lack of entrepreneurial tradition, the low level of education, and the lack of success patterns.

What are the means of encouraging rural entrepreneurship? One possible solution is attracting individuals using marketing techniques and entrepreneurtargeted promotions. A second solution is educational enlargement and 
improvement by including applicative disciplines in the educational programmes of the rural high schools and secondary schools. Another possible way of action is to positively influence the attitudes of community leaders towards local entrepreneurs. They could support the significant initiatives from the community and could attract firms from the outside (Doltu, 2011).

To conclude, rural entrepreneurship is an element of what should be today a large perspective of rural development. The rural entrepreneurship is more than providing agricultural credit and creating jobs in fields other than agriculture. All these should be integrated into strategies and programmes of rural development, together with human capital development, infrastructure, and social development (Doltu, 2011).

\section{The Romanian Rural Society}

Romania was a predominantly rural society until the coming of communism because around $80 \%$ of its inhabitants were living in the countryside. Even today, when the country is a member of the European Union, Romania is the country with the highest percentage of rural population (around 45\%). It is not by chance, therefore, that Romanian sociology has begun with the study of the rural areas, and thanks to its innovative contributions having its social roots in the Romanian rural reality it has become very well known in the international sociological world. This has become possible due to the prodigious research activity of the Bucharest Sociological School founded by Dimitrie Gusti.

The monographic research initiated by Dimitrie Gusti has been connected with the idea of the cultural development of the rural Romanian world. The research followed by action was in the opinion of Gusti the solution for the socio-economic development of the Romanian villages. The Romanian inter-war village was not only a place of the idyllic landscapes but also one of poverty, illiteracy, and of the illnesses caused by the misery. Even in these circumstances, at the end of the 1930s, there appeared a social segment of the middle classes known as "chiaburii" (kulaks). Unfortunately, these middle-class villagers were one of the "enemies" targeted by the communist power; they embarked on the forced collectivization of the agriculture, which began in 1949 in the southern and eastern regions of Romania and ended in Transylvania in 1962.

Collectivization, thinks Gheorghe Sişeştean - a sociologist and anthropologist from the University of Oradea (a distinguished colleague, who sadly passed away too early) -, represents "the last stage in the process of imposing communism in the Romanian society. To make tens of millions of people shut up was not a process which could be achieved overnight. Firstly, they eliminated the symbols that supported the peasantry: the institution of monarchy, political leaders, and 
intellectuals. This process had succeeded by 1949. Then the communist regime could pass on to the building of a new pattern of communist agriculture, a pattern of Soviet inspiration" (Şişeştean, 1999, p. 155, translation by authors). Şişeştean believes that "collectivization meant the end of the traditional village and also the end of peasantry. In this respect, the differences between Western Europe and Eastern Europe are considerable. "In the West, the end of the peasantry occurred through modernization, increase of productivity, and concentration of property, under the effects of the economic law of demand and supply [...] In Eastern Europe, the end of peasantry resulted from the imposition by force of an eclectic economic system where elements of modern agriculture lived in symbiosis with techniques of social exploitation and the confiscation of agricultural goods resembling tributary Asian and slavery economic systems" (Şişeştean, 1999, translation by authors).

In the socialist period, the radical transformation of the Romanian rural society through the industrialization and urbanization policies promoted by the Communist regime had as a consequence the decreasing of rural population from $76.6 \%$ in 1948 to $45.7 \%$ in 1990 . The peasantry was subjected to a process of proletarianization. The transformation of the peasant who practised subsistence agriculture into an industrial worker through the programme of massive industrialization started during the leadership of Gheorghe Gheorghiu-Dej and continued in the first two decades of Ceauşescu's era - this was the answer of the communist political regime to the needs of Romania's development. "Even if the industrialization and transformation of the peasantry into working class can be viewed as a necessary process for Romania's economic development, the actions of the communist regime were brutal and destructive for the world of the traditional Romanian village" (Mihalache et al., 2011, translation by authors).

The situation in the Romanian rural world changed dramatically after 1989. The first years of post-socialism witnessed the process of land reform. As a consequence of Law Nr. 18/1991, the agricultural co-operatives of production and state agricultural companies were abolished, and the land was distributed to the former owners within the limit of 10 hectares/family. This law was disputed by people who had possessed large territories before 1949 and were disadvantaged by the limit of 10 hectares. After 1996, the right-wing Romanian government changed the law of 1991 with another one, Law Nr. 169/1997, through which the maximum land size attributed to a family increased from 10 hectares to 50 hectares and from 1 hectare to 30 hectares in the case of the forests (Mihalache \& Croitoru, 2011, p. 30). As a consequence of these laws, the Romanian agricultural sector has been transformed from an intensive and export-oriented one into another one, oriented towards self-consumption.

Analysing the situation, Ilie Bădescu considers that "what has happened in the first 8-10 years of transition can be considered as a rural collapse [...] The rural population was exposed to a model of transformation characteristic of countries 
with rural underdevelopment. It is not about a polarization between the richer and the poorer but about an explosion of the two poles which are characteristic of underdeveloped countries: the employers and those living on subsistence economy" (Bădescu, 2003, p. 36, translated by authors). While the percentage of employees increased with $58.81 \%$, that of the employers increased by $400 \%$ and that of the unpaid rural people increased with $716.27 \%$. That is why Ilie Bădescu believes that in this case "polarization is not one of a capitalist type (employer - employee) but one of a new feudal type (employer - the self-subsisting rural)" (Bădescu, 2003, translation by authors).

The rural economy was broken away from the general economy as a consequence of the mentioned land reform laws. The Romanian peasant of the post-socialism reform was forced to rediscover the plough pulled by the donkey (because horses or modern technology were very expensive). Forced to subsistence agriculture and having to witness the state withdrawal from rural economy, the peasant is thrown few historical cycles back into feudal-type agriculture. The conclusion of the analysis is that "the reform which should have brought modernization and market economy brought in fact the ruralization of poverty, social structure disintegration, and rural neo-feudalism" (Bădescu, 2003, translation by authors).

Today, with 15.48 billion Euros as a total value of production, Romania is on the $8^{\text {th }}$ place in the European Union. However, if we focus on agricultural productivity, Romania is overtaken by many countries from South and Eastern Europe such as Poland, Hungary, and Greece. Romania has around $32.3 \%$ of the total number of farms of Europe (3.85 million) and from this total the majority is family farms, and only 30,000 are industrial farms. These statistics prove that Romania is practising an agriculture oriented to subsistence. Also, the productivity on hectare is very low. For instance, Romania, which has a productivity of 1,163 euros/hectare, overtakes only countries such as Bulgaria (852 euros/hectare) and Slovakia (1,126 euros/hectare), but it is overtaken by Poland (1,558 euros/hectare), Hungary (1,613 euros/hectare), and Greece (1,874 euros/hectare). ${ }^{6}$

From the point of view of the employed rural population's professional status, the evolution after the 1990s shows us a decrease in the number of employees (between 1996 and 2008, there has been a decrease of 25\%) caused by economic post-socialist transition, which also had as an effect the dramatic decrease in industrial activities. The number of rural employees had fallen from 4 million in 1996 to 1.56 million in 2006 (Mihalache \& Croitoru, 2011). The economic decrease of 1990-1992 and 1996-1999 resulted in a huge increase of those involved in subsistence agriculture as a life strategy. We have to add that these people are those from the poorest strata of the rural society. The professional status of these

6 "European leaders in agriculture but lagging in productivity," Adevărul (Romanian national daily), $24^{\text {th }}$ February, 2015, p. 11. 
people could be considered uncertain and they could be called neither farmers nor small entrepreneurs (Mihalache \& Croitoru, 2011).

The non-agricultural occupations of the rural population have abruptly decreased after 1990. Before 1990, a significant segment of the active rural population worked in the urban areas, in the industry, the construction sector, and in trading, while work places from the rural localities were predominantly in the agriculture. Commuting between villages and cities (which was a very central phenomenon before 1990) dropped back in the last two decades. Surviving non-agricultural work places are mainly those from the local administration, education, medical assistance, and trade. After 1990, the lack of opportunities at the local level, weak infrastructure, low professional training, and poverty were the main barriers of rural people searching for a workplace outside the agricultural sector. In absolute terms, the current situation of the population from the rural Romanian society who is occupied with non-agricultural activities is close to the levels measured in the 1930s and amounts to around half of the values from the 1970s (Mihalache \& Croitoru, 2011).

\section{The Hungarian Rural Society}

Similarly to Romania, the importance accorded to rural research and development in Hungary in the inter-war period arose from the modernization delay of the society as a whole and the needs derivable from this situation. The backwardness of rural areas has been interpreted by social researchers in the context of the overall transformation of society. Ferenc Erdei, a prominent Hungarian sociologist of the period, regarded rural society an inheritance of the feudal social structure and an obstacle in the process of the country's modernization (Kulcsár, 1983). He insisted on the need to search for solutions which are apt to simultaneously ensure the well-being of the village and the preservation of its traditional identity and values. In setting the theoretical and methodological ground for such an endeavour, the idea of Sociologia militans and the monographic method developed within the Bucharest Sociological School led by Dimitrie Gusti have been used as fertile sources of inspiration by Hungarian rural sociologists.

Like in all countries of the region, the hopes and aspirations nurtured by the social reformers were interrupted by the centralist projects of modernization initiated by communist governments. During the 1950s, Hungary, similarly to its neighbours, underwent a Stalinist phase of collectivization, which resulted in a sharp decrease in the rural peasantry's life standards. In the subsequent years, however, under the impact of the popular reactions against the centralistcollectivist agricultural system, the Hungarian communist political leadership developed a new model of collectivized agriculture. The Hungarian agricultural 
reform was implemented within the New Economic Mechanism. Initiated in 1968, the Reform offered to agricultural managers the opportunity to work in an economic environment which partially resembled the market conditions: no central plan objectives, a significant degree of autonomous decision-making and internal organization, and competition (Swain, 1992). Among the reform measures, one should mention the increasing of agricultural purchase prices, contract sales instead of compulsory deliveries, the higher wages coming closer to those in industry, and with social security benefits (Swain, 1998).

One of the main outcomes of the economic reform was the "second economy," which appeared earlier in Hungary compared to other countries in Central and Eastern Europe (Stark, 1996; Szelenyi, 1988). Szelenyi (1988) used the term "socialist entrepreneurs" to characterize household production farmers in Hungary in the last two decades of socialism. During this period, the agricultural population enjoyed a relative affluence and job security; therefore, during the regime change of 1989, the agricultural producers were rather reluctant to the idea of radical change.

After 1989, the assets of the co-operative farms were not destroyed or abandoned as in countries such as Bulgaria and Romania (Swain 1998) but were rather transformed into private large-scale successor farms. The transformation from a socialist to a capitalist mode of production was achieved through a sharp downsizing of industrial employment and coincided with a period of economic decline. In the period between 1988 and 1993, agricultural employment fell from 18.5 to 9.9 percent (Kovách, 1994). The share of agriculture within the economy declined from 14 percent to 6 percent of the gross domestic product between 1990 and 1997 (Kocsis, 1999).

The economic restructuring resulted in high unemployment and declining life standards (Szamuely, 1996), but, unlike in several other countries of Central and Eastern Europe, it did not lead to the fragmentation of the lands into small plots (Süli-Zakar et al., 1998). As most industrial working places were located in the cities and towns during socialism, economic downsizing was also most drastic in such places (Brown et al., 2005). During socialism, many of the displaced workers had strong family and community ties with villages (Brown, Schafft, 2002), and to them the decision of migrating back to their villages of origin seemed to be in many respects a natural option. However, only a few of them actually did so due to the fact that rural economy was relatively devoid of opportunities that would be expected to attract the urban unemployed to rural locations (Harcsa et al., 1998). Thus, the urban push was not accompanied by a rural pull. Moreover, rural workers have been adversely affected by diminished commuting possibilities in the nearby urban economies, which have been restructured and required far less labour. Both gross and net migration data indicate that Hungarians were not highly mobile during the early 1990s and that migration increased after 1996 as the economy recovered. 
On the other hand, the rural to urban commuting has been an important social phenomenon during post-socialism (Brown et al., 2005). The Hungarian households of today tend to use multiple sources of income, combining jobs in the official economy, the social security benefits, producing for own household consumption, as well as for selling in the market. This livelihood strategy, having its origins in peasant society, was amplified in socialism, and it still persists. The reduction of the social allocations and the increasing economic insecurity and instability are strong incentives for rural inhabitants to produce for their own consumption and/or exchange between households (Brown \& Kulcsar, 2001).

\section{Entrepreneurial Environment in Romania and Hungary}

Although today economic development differences between Romania and Hungary still persist, stronger links have developed between economic firms, public institutions, civil organizations, and university research entities within the Euro-region and steps have been made for strengthening the social and economic cohesion of the border area.

If we take a look at the economic map of Romania and Hungary, we can notice that the development gap and the difference in wages which still exist are of smaller amplitude and are less visible in the shared border region compared to the average situation of the two countries. In Romania, the western-located counties such as Bihor, Cluj, Timiş, alongside the county of Ilfov, which is in the neighbourhood of Bucharest, the capital city, and Constanța, the main harbour on the Black Sea Coast, are together the most entrepreneurial regions of Romania. On the opposite side, there are the counties in the eastern and southern parts of Romania such as Ialomița, Dâmbovița, Olt, Teleorman, Vaslui, and Botoşani. While the group of the more entrepreneurial counties is composed of those regions where there are important universities or large minority groups and/or very good conditions for economic activities (capital city, main harbour of the country), the low economic and social development of the second group of counties is probably the result of the absence of big universities and lack of large minorities.

Similarly to Romania, in Hungary, there are also important territorial differences concerning the socio-economic development and the characteristics of entrepreneurial environment. The most developed regions, apart from the capital Budapest and its surroundings (with a particularly high number of private entrepreneurs) are the western and south-western parts of the country (especially Győr-Moson-Sopron, Komárom-Esztergom, Csongrád, and Baranya counties), conveniently located geographically for the attraction of foreign capital, while the less developed areas are in the north-east (Szabolcs-Szatmár-Bereg, Békés, 
and Nógrád counties). ${ }^{7}$ Hajdú-Bihar County is part of the Northern Great Plain Region, which is among the geographical areas with a comparatively weak level of development, a relatively small number of enterprises, and a rather high number of unemployed people. The socio-economic situation is particularly weak in 13 Hajdú-Bihar localities, where the rate of unemployment is more than three times higher as compared to the national average rate. ${ }^{8}$

If we take a look at the statistics regarding entrepreneurial environments, we can notice that Romania and Hungary are very close in the world ranking regarding the ease of doing business, with Romania on a slightly better position. In the next table, we present this comparison for the year of 2013 (in this ranking, there are considered 189 countries from all over the world).

Table 1.

\begin{tabular}{lcc}
\hline & Romania & Hungary \\
\hline Ease of doing business & 48 & 54 \\
\hline Starting a business & 38 & 57 \\
\hline Dealing with construction permits & 140 & 103 \\
\hline Getting electricity & 171 & 162 \\
\hline Registering property & 63 & 52 \\
\hline Getting credit & 7 & 17 \\
\hline Protecting minority investors & 40 & 110 \\
\hline Paying taxes & 52 & 88 \\
\hline Trading across borders & 65 & 72 \\
\hline Enforcing contracts & 51 & 20 \\
\hline Resolving insolvency & 46 & 64 \\
\hline
\end{tabular}

Source: http://www.doingbusiness.org (accessed on: 20.08.2015)

While in Romania the elements considered to inhibit the entrepreneurial activities are state bureaucracy, corruption, excessive fiscality, and frequent legislation changing (Marinescu et al., 2007), in Hungary, lack of transparency, frequently changing rules and regulation, and overextension of state are considered the inhibitory factors of entrepreneurial activities and economic growth (Csaba, 2011).

\section{Research Methodology}

What we would like to succeed in our paper is to explain and understand some important issues concerning rural youth involvement in entrepreneurship and agriculture in Romania and Hungary, viewed in a cross-border comparative

7 http://mek.niif.hu/06400/06407/06407.pdf (accessed on: 13.10.2014)

8 rs1.szif.hu/ pmark/publikacio/Netware/koncz.doc (accessed on: 13.10.2014) 
perspective. The study is based on the survey data collected in the Bihor - HajduBihar Euro-region during the period of 2012-2013, from a random sample of 1,000 Hungarian and Romanian young villagers. The questionnaire included questions regarding rural youth integration in the labour market, involvement in agriculture and entrepreneurial activities, as well as social and religious participation.

The main questions tackled in this paper are: What does the land mean for young villagers in Romania and Hungary? Do they cultivate the land on large, middle, or small surfaces? What type of crop do they cultivate? What kind of animals do they raise? Do they practise an agriculture oriented to self-consumption or rather one oriented to the market? Are they open towards entrepreneurial activities? Do they have business opportunities? Do Hungarian villagers have a higher degree of modernity than Romanians do?

\section{Owning and Cultivating the Land}

If we take a look at the surface of the land owned by the subjects and their families (figures 1 and 2), we can notice that in the vast majority of the cases both in Romania and Hungary small terrains or those less than 1 ha are the most prevalent. While in Hungary there are many cases of subjects without land $(11.2 \%)$, in Romania, there are only few such cases $(1 \%)$. The subjects that report larger surfaces, between 1 ha and 4 ha, are around 15.7\% in Romania and 7.7\% in Hungary. In small proportion, there are reported also terrains larger than 4 ha ( $3.7 \%$ in Romania and $4.2 \%$ in Hungary).

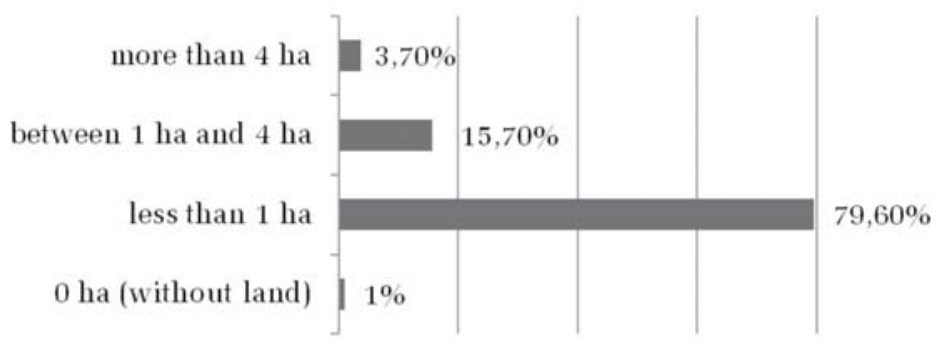

Figure 1. Surface of land owned by subjects and their families in Romanian villages

How could we interpret these data? Could we conclude that in this case the Romanian villagers' situation is slightly better than of those in Hungary? First of all, in both countries, the small property dominates in the rural area. We hardly have cases of properties between 10 ha and 50 ha which would be called middlesized properties. Still, there is an important difference. While in the researched villages from Hungary there are agricultural associations of villagers that cultivate 
their lands in common, in the Romanian villages covered by our comparative study, everybody cultivates their land with the family.

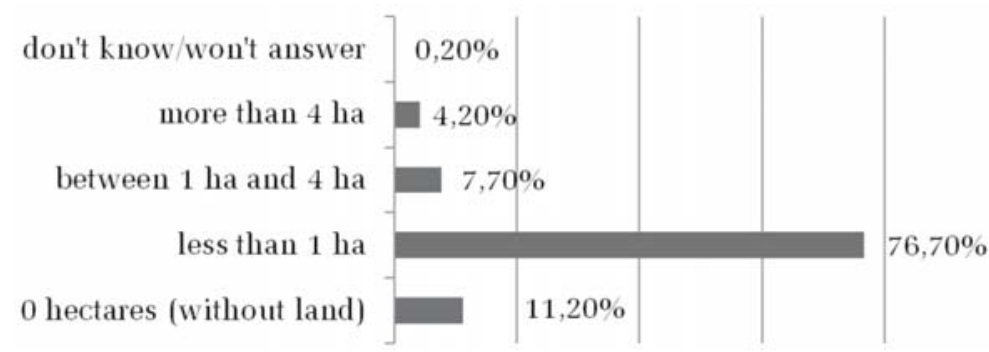

Figure 2. Surface of land owned by subjects and their families in Hungarian villages

Two villages from Hungary, Tepe and Konyár, are $30 \mathrm{~km}$ distance from Debrecen, the main city of the Hajdú-Bihar County. Derecske is around $20 \mathrm{~km}$ distance from Debrecen, while Sáránd and Hosszúpályi are around $15 \mathrm{~km}$ distance from the same city. The villages in Romania are either in the neighborhood of the main city, Oradea (no more than $15 \mathrm{~km}$ distance - Borş, Nojorid, and Oşorhei), or within a small distance such as Hidişelu de Sus $(20 \mathrm{~km}$ from Oradea) or even within a greater distance as Vadu Crişului (50 km from Oradea). We think that the fact that in Hungary more subjects reported they had no land denotes a better socioeconomic situation of the rural population in Hungary as compared to Romania. These "landless" rural inhabitants are in fact people from the main city of the county, who bought houses in the sub-urban area. In Romania, these cases are less frequent than in Hungary (only 1\%). And we can conclude that this process of suburbanization and urban-rural migration - which indicates a modernization of rural society - is more advanced in Hungary.

One of the questions from our survey was: "What does the land mean for you?" As you can see in Figure 3, for Hungarians, the land means the main source of living in a higher percentage $(27.7 \%)$ than in the case of Romanian young villagers (11.1\%). A greater percentage of Hungarians (42\%) than that of Romanians (8.7\%) believes that "even if not profitable, land must be cultivated" (Figure 4). Also, the Hungarians $(9.3 \%)$ are in a higher percentage than Romanians $(2.9 \%)$ in favour of the idea that "land must not be sold because it represents a fortune that continues to grow" (Figure 5).

Could we understand from these figures that Hungarians are more attached to their land and their village than Romanians? We believe that the answer is positive. The explanation could be the fact that most Romanian villages from our sample are closer to the main city of the county than the villages of the Hungarian case. The tendency for migration from rural villages in the Western countries is higher in Hungary than in Romania, and this could be another explanation. 


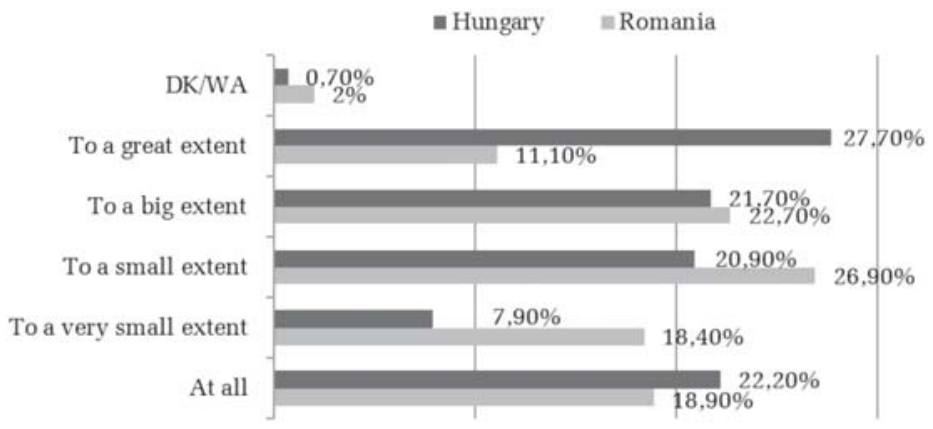

Figure 3. Land, the main source of living

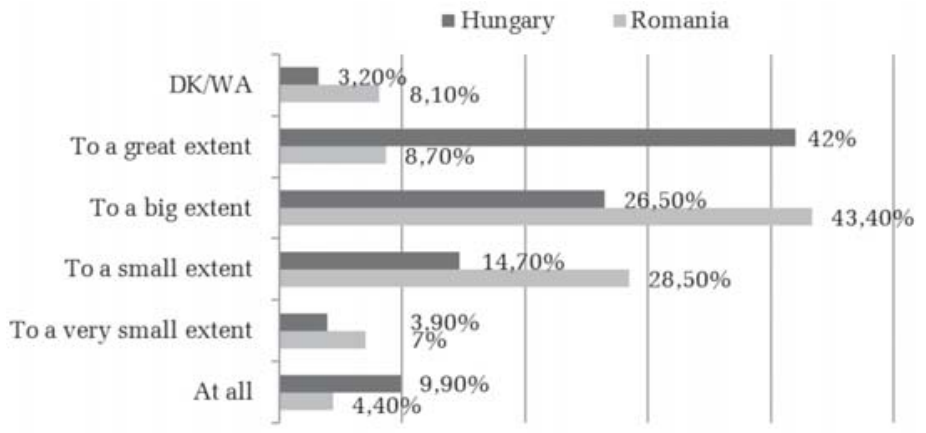

Figure 4. Even if not profitable, land must be cultivated

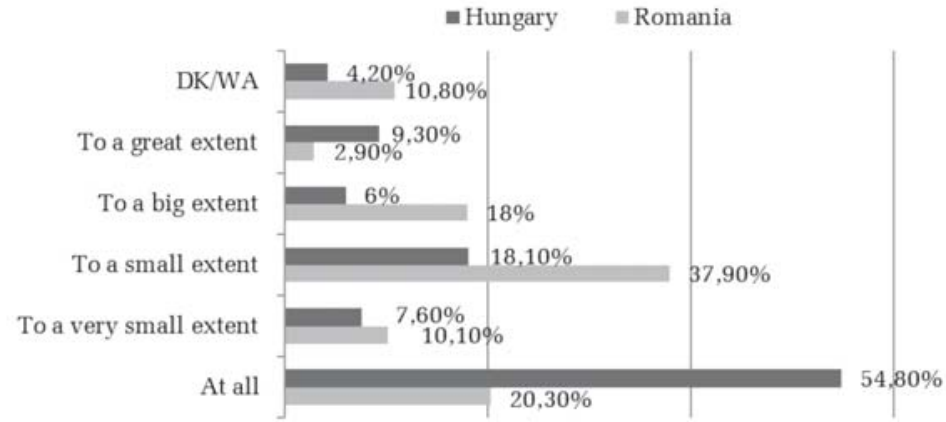

Figure 5. Land must not be sold; it represents a fortune that continues to grow 


\section{Cultivating the Land}

As we can notice from the figures 6 and 7, the villagers both in Romania and Hungary cultivate a large variety of crops such as wheat $(26.3 \%)$, corn $(25.1 \%)$, and oat $(0.80 \%)$ in Romania and corn $(45.42 \%)$, wheat $(28 \%)$, and sunflower $(15.4 \%)$ in Hungary. We observe in the Romanian case that there are many cases of villagers who cultivate vegetables (42.8\%), while in Hungary the focus is on corn crops. Probably, the statistical results are influenced by the fact that Hungarian agriculture is more oriented to co-operative farms, while in Romania family farms are dominating.

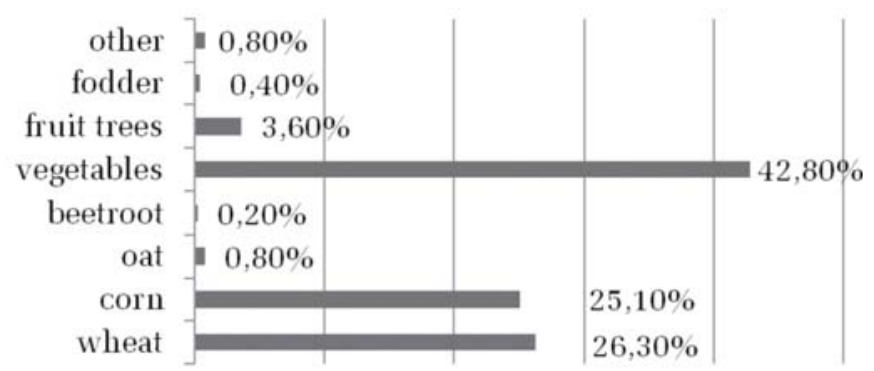

Figure 6. What are the cultivated crops? The Romanian case

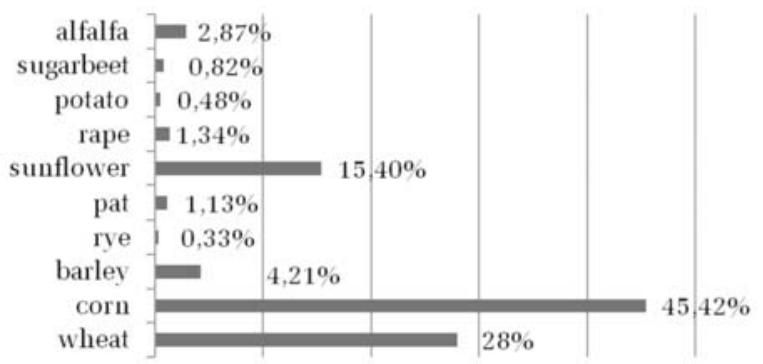

Figure 7. What are the cultivated crops? The Hungarian case

But even if there are less young Hungarian villagers who cultivate the land together with their families, there are more Hungarians (12.9\%) than Romanians $(3.7 \%)$ who sell the products on the market (Figure 10), a fact which denotes a higher degree of market orientation in the case of Hungarian farmers and a high degree of modernity. 


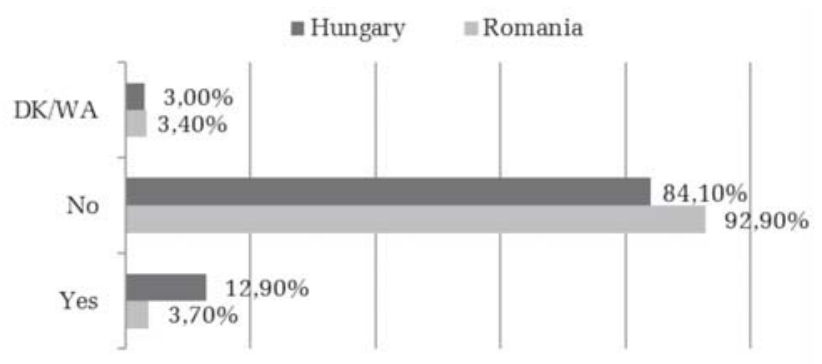

Figure 8. At present, is your family selling the end products on the market?

\section{Raising Animals}

If we take a look at the figures representing animal husbandry, we can figure out that there are more Romanian young villagers $(57.7 \%)$ who raise animals in comparison with $31.3 \%$ of the Hungarians. In Romanian villages, there is a large variety of animals raised (pigs, cattle, poultry, sheep, horses, and rabbits); in Hungarian villages, the young villagers raise only cattle and pigs. This result could also be influenced by the prevalence of co-operative farms in the Hungarian case and by that of the small family farms in the Romanian case.

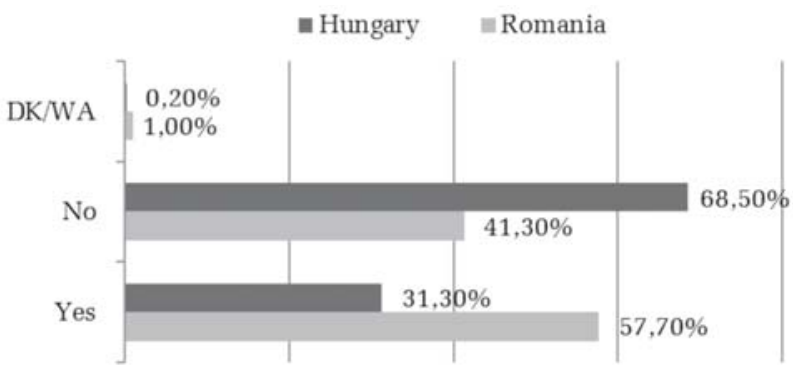

Figure 9. At present, do you raise animals?

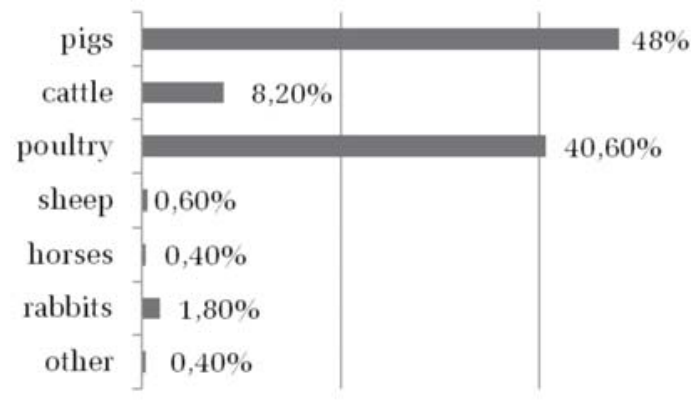

Figure 10. What kind of animals do you keep? The Romanian case 


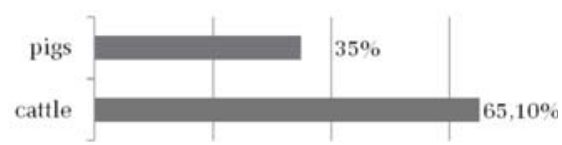

Figure 11. What kind of animals do you keep? The Hungarian case

Similarly to the case of selling crop end products on the market, the Hungarian villagers are selling animal products on the market in a larger percentage than Romanians do (12.9\% compared to $3.7 \%)$, which shows that Romanians produce more for self-consumption, while Hungarians practise a market-oriented agriculture to a greater extent. These comparative data point to a higher degree of modernity in the case of Hungarian young rural inhabitants.

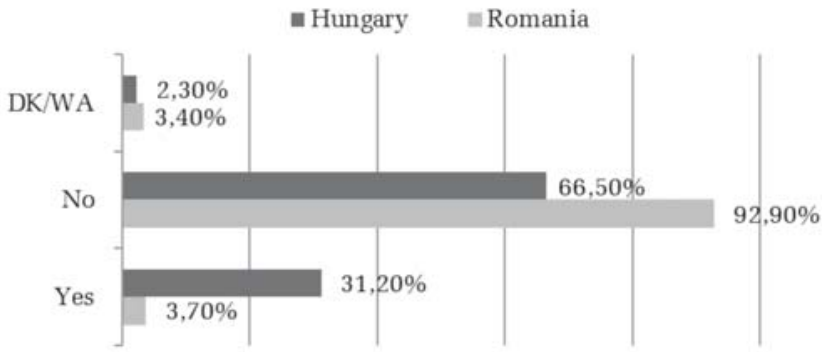

Figure 12. At present, are you or your family selling animals or animal products on the market?

\section{Entrepreneurship as an Intention and as a Fact}

Looking at Figure 13, we can notice some interesting aspects. Firstly, as far as the declared intention to open a business is concerned, Romanian young villagers have higher percentages than Hungarians. $77 \%$ of the Romanians are in favour of opening a business in comparison with only $55.3 \%$ of Hungarians. Similarly, only $18 \%$ of Romanians declared they are not in favour of opening a business compared to $38 \%$ among the Hungarians. If we look, however, at those who already have a business, Hungarians are in a slightly more favourable position than Romanians.

Concerning business opportunities in the residential area (Figure 14), Romanians seem to have better perspectives. $22.8 \%$ of Romanian young villagers consider they have very big or big opportunities in comparison with $6.8 \%$ in the case of Hungarians. Also, 73\% of Hungarians consider they have small or very small opportunities in comparison with $42.7 \%$ among the Romanians. Apparently, there is another paradox here. If they have better opportunities, why do Romanians have fewer businesses than Hungarians? 


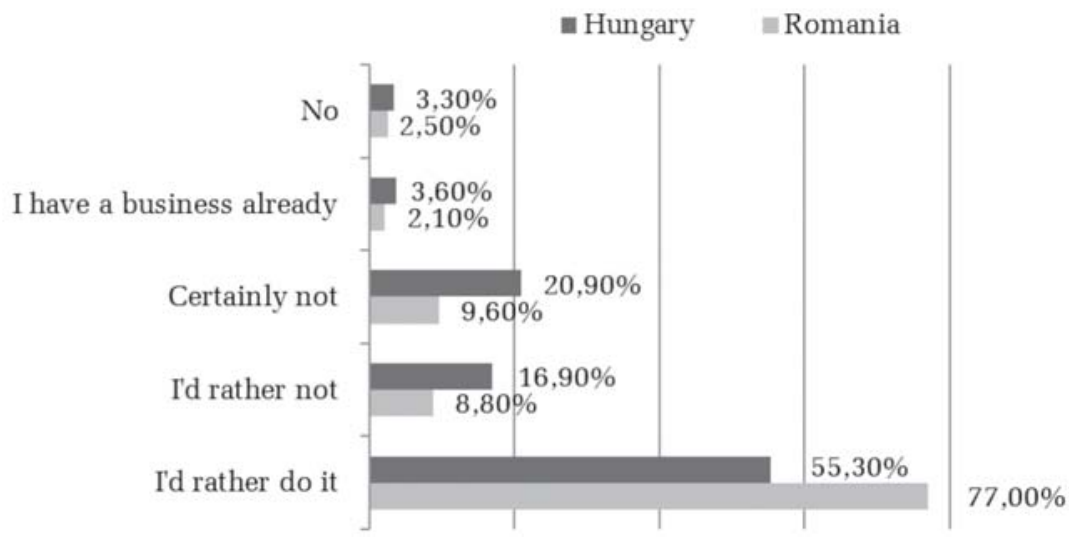

Figure 13. Would you be willing to open a business of your own?

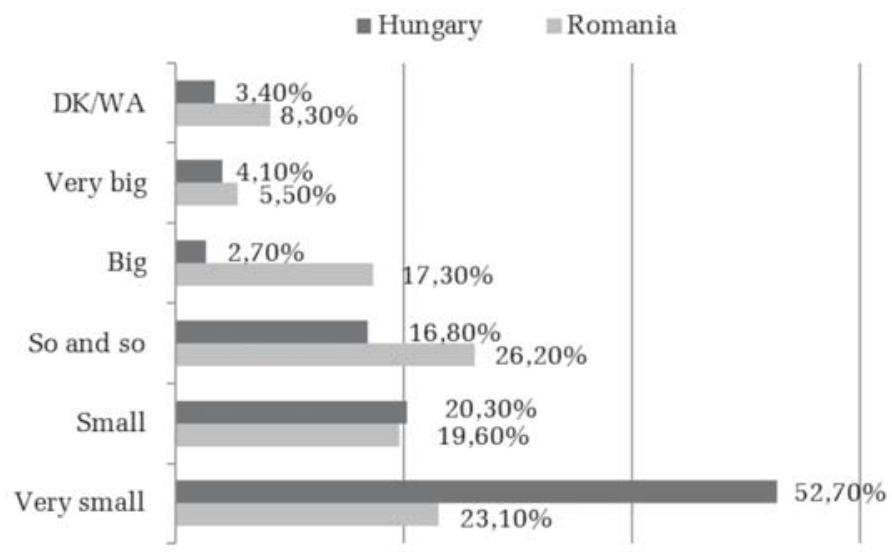

Figure 14. Business opportunities in the residential area

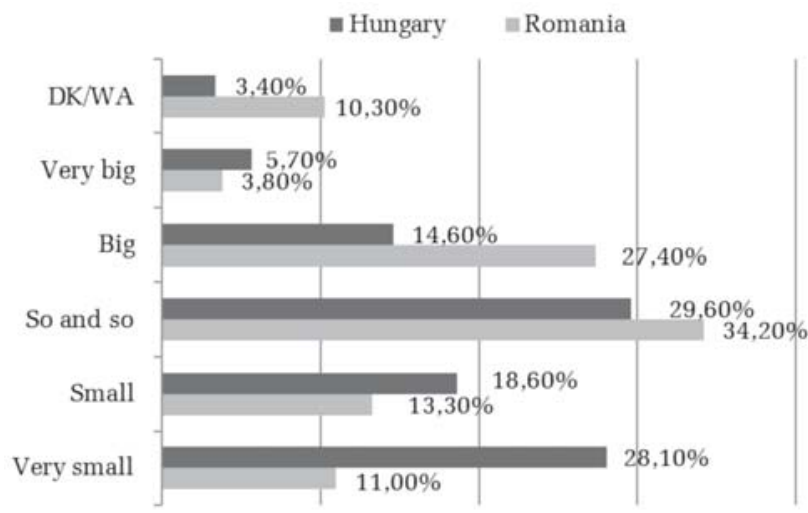

Figure 15. Business opportunities in the city, in the county 
If we focus on the perceived business opportunities at county and main city level (meaning Debrecen and Oradea), Romanians seem to be more optimistic than Hungarians. $31.2 \%$ of Romanians and only $20.3 \%$ of Hungarians consider that they have business opportunities in the main city and generally within their own county. Similarly, $46.7 \%$ of Hungarians consider that they have small or very small oportunities in comparison with $24.3 \%$ of the Romanians.

Thus, our data suggest that even if Hungarian young villagers are not as optimistic as Romanians regarding business opportunities within their own residential area and at county level, in fact, they own a slightly greater number of businesses than Romanians do. This means that although Romanians have a higher score as intentional entrepreneurs, Hungarians are comparatively more successful in actually starting their own businesses. The result is explained by the prevalence of co-operative farms in the Hungarian case, which are oriented in a much higher degree to the market than the small family farms of Romanians are oriented to self-consumption.

\section{Conclusions}

The idea of this comparative research emerged from the need to integrate the euro-regional outlook and the cross-border approach into the research and development activities within the shared border region of Romania and Hungary. We believe that in order to maximize its efficiency, integrated development should be based on an in-depth knowledge of socio-economic realities, presupposing a set of indicators and the use of a shared methodology of data collection and interpretation. The research instruments developed within the project and applied in a unitary manner in the selected rural communities at both sides of the border permitted us to obtain relevant and comparable information.

Our historical overview points to the fact that the development routes of agriculture and the rural areas in Romania and Hungary present some essentially similar characteristics but also significant differences. Until the epoch of "socialist modernization" in both countries, the rural and agricultural population was the source of living for the great majority of population, but due to its low productivity it could ensure only modest living standards for most families. In spite of the fact that during the inter-war period internationally recognized sociological research initiatives in both countries focused on how to achieve rural and agricultural modernization, no radical breakthrough could be made in this respect before the communist takeover, which - in contrast to the previous gradual reform initiatives - prompted the start of an abrupt and centrally imposed transformation in both societies. 
In order to overcome the persisting modernization gap and to consolidate their own social basis, the communist regimes subjected both Romania and Hungary to forced collectivization and industrialization, managing to dislocate a large part of population from the villages to the cities and towns. In only a few decades, the proportion of those living in agriculture dropped sharply and the nature of agricultural work changed radically, putting in fact an end to the traditional peasant way of living. However, after the suppression of the 1956 anti-communist revolution in Hungary, Hungarian and Romanian agriculture experienced rather different paths of development. While in Romania forced collectivization and industrialization continued to aim at the destruction of the spirit of initiative and self-management, which was characteristic to the traditional peasant economy, in Hungary, the communist leadership strived to achieve a kind of new "reconciliation" with the peasantry. Agricultural cooperatives were granted a large degree of autonomy from the central leadership and were permitted to take economically grounded decisions in order to enhance the individual well-being of their members.

After the collapse of the communist regime, re-privatization of the collectivized agricultural farms occurred in both countries, but in rather different conditions and with different consequences, partly derivable from the different realities inherited from the socialist period. In Romania, where collective farms were rightly perceived as another form of state property and of state exploitation of cheap agricultural workforce, most of them were quickly dissolved and replaced by small individual peasant farms bound by their small size and other economic constraints to produce predominantly for subsistence and self-consumption. In contrast, in Hungary, peasants had the opportunity during socialism to experience the advantages of co-operative work in large farms, and therefore the political chances for preserving this more market-oriented form of labour organization in the post-socialist period were much more favorable than in Romania.

These diverging socio-historical conditions - along and in combination with differences in the level of economic development and modernization should be regarded, in our view, as key explanatory factors of the results of our research, which show that Hungarian young people involved in agriculture are producing to a larger extent for the market, have more entrepreneurial initiatives, and perceive greater opportunities in their own home region as compared to Romanian young villagers. Hungarian rural inhabitants live in a comparatively more consolidated socio-economic environment, which was less affected by discontinuity as compared to the Romanian villages. The Romanian rural world lives in a higher degree of economic uncertainty and has to use to a larger extent compensatory modes of earning an income such as seasonal agricultural work or migrant work abroad. Perhaps the comparatively stronger presence among the researched Romanian young villagers of the intention to start their own business 
can be partly explained by the comparatively more precarious living conditions that the local agriculture can offer to local rural inhabitants in Romania.

Perhaps the most viable solutions would require cluster analyses of rural areas due to the fact that there are major demographic and socio-economic differences between these zones. Thus, specific measures need to be taken, adapted to the actual needs and potential of each area (Weingarten, 2004). In this regard, rural typologies can be useful instruments for the design of development policies for rural areas, based on the recognition that the addressed issues are multi-dimensional (Oláh \& Pakurár, 2011). Another possibility emphasized in the specialized literature refers to redefining rural development policies based on a new paradigm of rural development by including the concept of network (Murdoch, 2000). Murdoch mentions two network categories: the vertical, which connects the rural to the agriculture and food sectors, and the horizontal, which connects rural spaces to the non-agricultural processes generated by economic changes.

Taking into account the important differences between the socio-economic environments in the two countries outlined above, we think that the potential solutions and strategies of development should be adapted as much as possible to the particular conditions of the two countries and also to the specific circumstances of each individual rural locality. In Hungary, efforts should be made in order to encourage local villagers to assume more risks in taking autonomous life decisions and in trying new opportunities and alternative sources of income. In the case of Romanian young rural inhabitants, the stress in counselling and community building activities should probably be laid mainly on persuading villagers to stay in or to return to their home places, and on assisting them to identify and develop new job opportunities (including entrepreneurial and selfemployment solutions) at local level.

In these efforts, stakeholders at local and regional levels should play an essential role. Decentralization of decision-making should be implemented, taking into account that local communities dispose of the best knowledge about the employment needs and opportunities, and the resources within the local community. Local governments, civil organizations, and individual citizens from the two neighbour countries and regions, including the young people themselves, should learn from one another and establish links of co-operation.

The data from our quantitative research convinced us that a qualitative approach that would refine the quantitative data would be necessary for the near future or a next research project. It would be interesting to know the opinions of different local leaders from the villages in the Bihor-Hajdú-Bihar Euro-region regarding the problems such as agriculture, co-operative-farms, individual farms, and entrepreneurship and future opportunities for the rural youth. The research also raises questions regarding the linkage between the economic environment 
of the region and entrepreneurial opportunities and activities. Maybe a future research of our team will be dedicated to this topic.

\section{Summary}

Our approach is based on the quantitative data analysis. The authors were experts in the mentioned project developed between 2012 and 2013 in Romania and Hungary. Our team collected 1,000 questionnaires using a random sample of young villagers from 10 rural communities of Bihor and Hajdú-Bihar counties.

\section{References}

Bădescu, I. (2003). Țăranii şi noua Europă. Bucharest: Mica Valahie Publishing House.

Brown, D. L.; Kulcsar, L. (2001). Household economic behavior in post-socialist rural Hungary. Rural Sociology June, 66(2). ISSN 0036-0112.

Brown, D; Kulcsár L. J.; Kulcsár L.; Obadovics, C. (2005). Post-socialist restructuring and population redistribution in Hungary. Rural Sociology 70(3): 336-359.

Brown, D. L.; K. A. Schafft. (2002). Population deconcentration in Hungary during the post-socialist transformation. Journal of Rural Studies 18: 233-244.

Crihan, E. (2011). Mentalități rurale în România de tranziție. Un studiu de caz în județul Sălaj. University of Oradea Publishing House.

Croitoru, A. (2013). Digging among the roots of entrepreneurship. Journal of Community Positive Practices XIII(1): 129-147.

Csaba, L. (2011). The challenge of growth. Hungarian Review, May. Budapest.

Doltu, C. (2011). Mediul rural între supraviețuire şi oportunități de afaceri. Bucharest: Expert Publishing House.

Drucker, P. (1993). Inovația şi sistemul antreprenorial. Bucharest: Enciclopedica Publishing House.

Harcsa, I.; I. Kovách; Szelényi, I. (1998). The price of privatization: the postsocialist transformational crisis of the Hungarian agricultural system. In: Szelenyi, I. (ed.), Privatizing the land: rural political economy in postcommunist societies. New York: Routledge. pp. 214-244.

Kocsis, G. (1999). Ten years of hard labor: the rebirth of capitalism. Hungarian Quarterly 40: 64-71.

Kovách, I. (1994). Privatization and family farms in Central and Eastern Europe. Sociologica Ruralis 39: 369-82. 
Kulcsár, K. (1983). Rural development in post-war Hungary. Sociologia Ruralis 23(3/4): 7.

Marinescu, C.; Glăvan, B.; Staicu, G; Pană, M.; Jora, O. (2007). Capitalismul. Logica libertății. Bucharest: Humanitas Publishing House.

Mihalache, F.; Croitoru, A. (2011). Mediul rural românesc: evoluții şi involuții. Schimbare socială şi antreprenoriat. Bucharest: Expert Publishing House.

Murdoch, J. (2000). Networks: a new paradigm for rural development? Journal of Rural Studies 16: 407-419.

OECD. 2009. Tackling the jobs crisis. The labour market and social policy response. OECD Labour and Employment Ministerial Meeting. Paris: OECD Publishing.

Oláh, J.; Pakurár, M. (2011). The Karcag and Hajdúszoboszló LLS (Hungary): opportunities for, and constraints on, rural economic diversification. Österreichischen Gesellschaft für Agrarökonomie, pp. 151-152.

Olah, Ş. (2013). Oameni şi organizații. Cluj-Napoca: Eikon Publishing House.

Popescu, R. (2011). Grupurile vulnerabile şi economia socială. Romi şi femei în dificultate. Bucharest: Expert Publishing House.

Şişeştean, G. (1999). Forme tradiționale de viață țărănească. Zalău: Centrul de Conservare şi Valorificare a Tradiției şi Creației Populare Publishing House.

Süli-Zakar, I.; Sántha, A.; Tykkylainen, M.; Neil, C. (1998). Coping with socialist restructuring and the transition to a market economy in rural Hungary. In: Neil, C.; Tykkylainen, M. (eds), Local economic development. New York: United Nations University Press, pp. 125-53.

Stark, D. (1996). Recombinant property forms in Eastern European capitalism. American Journal of Sociology 101: 993-1027.

Szelenyi, I. (1988). Socialist entrepreneurs: embourgeoisement in rural Hungary. Madison: University of Wisconsin Press.

Szelenyi, I.; Kostello, E. (1998). Outline of an institutionalist theory of inequality: The case of socialist and postcommunist Eastern Europe. In: Brinton, M. C.; Nee, V. (eds), The new institutionalism in sociology. New York: Russell Sage Foundation, pp. 305-326.

Swain, N. (1992). Hungary: the rise and fall of feasible socialism. London, pp. 85-151.

Swain N. (1998) A framework for comparing social change in the post-socialist countryside. Eastern European Countryside 4: 5-18.

Swedberg, R. (2000). Entrepreneurship. The social science view. Oxford University Press.

Szamuely, L. (1996). The social costs of transformation in Central and Eastern Europe. Hungarian Quarterly 37: 54-78.

Voicu, M.; Voicu, B. (2006). Satul românesc pe drumul către Europa. Iaşi: Polirom Publishing House. 
Weingarten, P. et al. (2004). The Future of rural areas in the CEE new member states. IAMO, Halle, (http://ec.europa.eu/agriculture/publi/reports/ccrurdev/ text_en.pdf, accessed on: 23.09.2013)

“Adevărul” Journal, February 24 $4^{\text {th }}, 2015$, p. 14 (available on: http://www.adevarul.ro).

http://www.rupri.org/Forms/RuralDefinitionsBrief.pdf. (accessed on: 18.08.2015).

http://www.territorialcooperation.eu/frontpage/show/23625 (accessed on: 25.11.2014).

http://www.capital.ro/somajul-in-randul-tinerilor-a-ajuns-la-257-in-romania.html (accessed on: 3.11.2014).

http://index.hu/chart/2014/09/24/oecd/ (accessed on: 12.10.2014).

http://adlearning.creathink.ro/uploads/publicari/12918_researchstudy\%20 hu\%20jo.pdf (accessed on: 15.09.2014).

http://www.negyedev_munkaero_megyei_2011IIne_hajdu\&ei=gcz-VMPxPMa9U aWzhLAN\&usg=AFQjCNHuMnfV-RfGbjhfuwIdtlcFP5x5iw\&bvm=bv.8761140 1,d.d24 (accessed on: 29.09.2014).

http://ruralyouthjobs.ro/en/project-prezentation/ (accessed on: 20.10.2014). http://www.doingbusiness.org (accessed on: 20.08.2015).

http://mek.niif.hu/06400/06407/06407.pdf (accessed on: 13.10.2014). http://www.rs1.szif.hu/ pmark/publikacio/Netware/koncz.doc (accessed on: 13.10.2014). 